\title{
Study of the effects of check dam construction on the Limau Manih river using GIS
}

\author{
Darwizal Daoed $^{1 *}$, Fifi Novia Azhari ${ }^{2}$, Masril Syukur ${ }^{1}$, and Rudy Ferial ${ }^{1}$ \\ ${ }^{1}$ Departement of Civil Engineering, Faculty of Engineering, Andalas University, West Sumatera, Indonesia. \\ ${ }^{2}$ Graduate, Departement of Civil Engineering, Faculty of Engineering, Andalas University, West Sumatera, Indonesia.
}

\begin{abstract}
The problem of flooding or flash floods in watersheds often occurs, both in large rivers and small rivers. The frequency of occurrence varies greatly depending on the local climate. As a result of flooding, it causes more erosion and collapse of riverbanks and washes away all kinds of materials, such as wood, sand, and stone. Sometimes it also submerges rice fields, villages, and houses downstream of the river. Likewise, in the study location of the Limau Manih river, there has been a flood with a large discharge. It was recorded twice a year, namely in July and September 2012. One of the ways to reduce energy, scour, and avalanches on riverbanks is by building a check dam or weir. A check dam is expected to reduce the energy that arises due to differences in elevation or slope of the river channel. But on the other hand, the weir will raise the water level, so that the puddle becomes wider. Therefore, it is necessary to study the impact of weir construction on the extent of inundation. The study was conducted using ArcGIS to map inundation and HEC-RAS to simulate water levels along the river. Simulations were carried out for several return periods of rainfall events. The results of the study show that the planned flood discharge in the river of Limau Manih watershed is quite large. Meanwhile, from the simulation results, the inundation area is not too significant with the increase in the return period and the planned flood discharge. Although the simulation of the weir without widening the upstream part of the weir shows a significant increase in inundation area. This is most likely due to the weir in the upstream area of the river which is rather steep, so that water flows quickly through the overflow of the weir. However, the water level in the weir is higher than without the weir, as a result, water jumps and erosion occur downstream of the weir. For this reason, it is very necessary to monitor the scour behavior in the weir and the sedimentation rate, because this area has the potential to be eroded.
\end{abstract}

\section{Introduction}

\subsection{Background}

High rainfall and short duration are very likely to cause flooding or inundation, where the water discharge will be high. Sudden flooding or flash floods or what is called Galodo by the local people of West Sumatra, Indonesia, hit the Padang City area of West Sumatra twice in 2012, 4 July 2012, and 12 September 2012. The flood washed away all kinds of materials, sand, stones, wood. and mud. In the lower reaches of Batang Kuranji in the Kuranji watershed, several locations were found to be inundated by water. The water level rises quickly, due to rain that occurs in the afternoon, and at the same time, high tide occurs in the coastal area. Flooding accompanied by high tides is a case of accelerating the occurrence of local inundation in the Padang city basin area [1,2].

Long before, flash floods also occurred in 1988 and March 16, 2008, in the Batang Kuranji and Batang Limau Manih streams. The flash flood that occurred in Batang Kuranji was caused by high rainfall and a decrease in the riverbed due to mining of rock, sand, and high velocity. Excessive natural management carried out by the community harms the preservation of nature and forests in the watershed [3]. To reduce the risk of flood events, flood and sediment controllers were built in the Batang Kuranji watershed in the Upper Segment. Check dams were built in three places along Batang Limau Manih which is a tributary of the Kuranji River in the Limau Manih sub-watershed. The Ministry of Public Works and Public Housing (PUPR) through the Sumatra River Basin Agency (BWS) V Directorate General of Natural Resources in Batang Kuranji and Batang Limau Manih and was completed in 2018 [4].

Even so, local flooding still occurs around the construction site of the Batang Kuranji check dam in the middle segment. However, it is not known with certainty whether the flood control building was due to the flood control building or the location being lower than the river embankment. Because when the discharge is large, the water level at the check dam is close to the height of the embankment but is still at a safe elevation. This means that it is still necessary to study what causes local inundation.

Based on the statement above, a study was carried out on the impact of the construction of flood and sediment controllers in Batang Limau Manih (Limauu Manih River) on the water surface area of the river and its surroundings using the geographic information system.

\footnotetext{
* Corresponding author: darwizaldaoed@gmail.com
} 


\section{Literature study}

\subsection{Floods}

A flood is an increase in the volume of water that exceeds the capacity of the channel/river, causing an area of land to be submerged [5]. The volume of water is not a problem if it does not cause losses, victims die or are injured, does not soak settlements for a long time, does not soak rice fields, and does not interfere with community activities. On the other hand, a time-consuming inundation is called a flood disaster.

\subsection{Construction of control sediment}

Construction of control sediment is water structures in rivers that function as sediment retainers, gravity type, or other types [6]. Check dam can control the speed, discharge, and direction of sediment flow, accommodate sediment both permanently and temporarily and consist of a weir body including foundations, overflows that can be overflowed. sediments, wings, and complementary buildings whose crests are overflowed by the flow of water $[7,8]$.

\subsection{Catchment Area}

A catchment area or rainwater catchment area is a small scale area of a watershed which means an area bounded by topographical barriers in the form of ridges or mountains that collect rainwater that falls on it and then drains it through creeks and rivers to the sea or lake $[9,10]$. The catchment area or water catchment area is estimated by contour line guidelines or the height of an area, the direction of flow from the conveyor channel to the main drain is usually used as a reference in the division of the catchment area.

\subsection{Flood Discharge Analysis}

To estimate the discharge in a watershed, where there is no discharge observation data, a design flood discharge analysis method is needed. One method that is often used is the Rational Method [2], [11], [12]. The flood discharge in this method is formulated as follows:

$$
\begin{aligned}
& \mathrm{Q}=1 / 3.6 \mathrm{C} \text { I A } \\
& \text { Where, } \\
& \mathrm{Q}=\text { discharge }\left(\mathrm{m}^{3} / \mathrm{sec}\right) ; \\
& \mathrm{C}=\text { runoff coefficient, } \\
& \mathrm{I}=\text { intensity }(\mathrm{mm} / \text { hour }) ; \\
& \mathrm{A}=\text { area of the watershed }\left(\mathrm{km}^{2}\right)
\end{aligned}
$$

\subsection{Geographic information system}

Geographic Information System (GIS) is a form of information that presents information in geographic form by using a map as an interface. GIS is used as a tool to process land mapping and analyze all events that occur on earth in a computerized manner, then integrate it into database operations and statistical analysis and combine it with unique geographical analysis through mapping or using maps $[13,14]$.

\section{Methodology}

The methodology applied in this research is firstly collecting climatic data, river geometry, and downloading basic digital elevation model (DEM) data and maps from google earth pro, secondly carrying out the process of forming a map of watersheds and surface runoff directions. Then do the simulation using Hec-RAS software.

The location of the weir is mapped only $1.0 \mathrm{~km}$ upstream and downstream of the weir, and in a transverse direction as far as $200 \mathrm{~m}$ perpendicular to the river.

Then rainfall analysis uses statistics and frequency for maximum daily rainfall. The results of a representative rainfall analysis are used to determine the design flood discharge. Flood discharge is calculated using the rational method.

Furthermore, the determination of the rain catchment area or watershed from the location of the weir to the upstream of the river. The area of the flow is done using ArcGIS. At the same time determine the direction of flow (flow direction). This process is carried out after interpolating the DEM data and combining it with tools in ArcGIS.

Finally, simulate the inundation surface area with conditions before and after the existence of sediment and flood control buildings using HEC-RAS. Each maximum plan debit is obtained with several return periods. The target of the simulation is to be able to describe the phenomena that will occur due to an increase in the amount of flow discharge.

\section{Result and Discussion}

\subsection{Formation of catchment map}

The flood simulation model requires input data in the form of a digital elevation model (DEM). DEM is the result of downloading through the DEMNAS website. The downloaded DEM is then processed using ArcGIS software. Where ArcGIS uses data management tools. Several DEMs are combined into a single raster and then clipped according to the Batang Kuranji watershed boundary.

In Fig. 1. DEM for Kuranji river watershed and Fig. 2. Flow direction for Kuranji river watershed, it can be seen that the dark blue area is an area with a higher elevation. The lighter blue color in the DEM indicates a lower area. Then the picture on the right shows the pattern of the direction of the water flow towards Batang Kuranji. In addition, it can also be seen which areas are the ridges or peaks as the topographic boundary for the formation of watersheds.

The next process is to process the flow direction map into a river network map and the distribution of catchment areas in the Batang Kuranji watershed using Spatial Analyst Tools. The results of the spatial analysis show that several catchment areas are formed, one of which is the Batang Limau Manih catchment area which is the river where the sediment control structures will be studied. The catchment area of Batang Limau Manih obtained from the results of spatial analysis in ArcGIS software is $30.0 \mathrm{~km}^{2}$. 


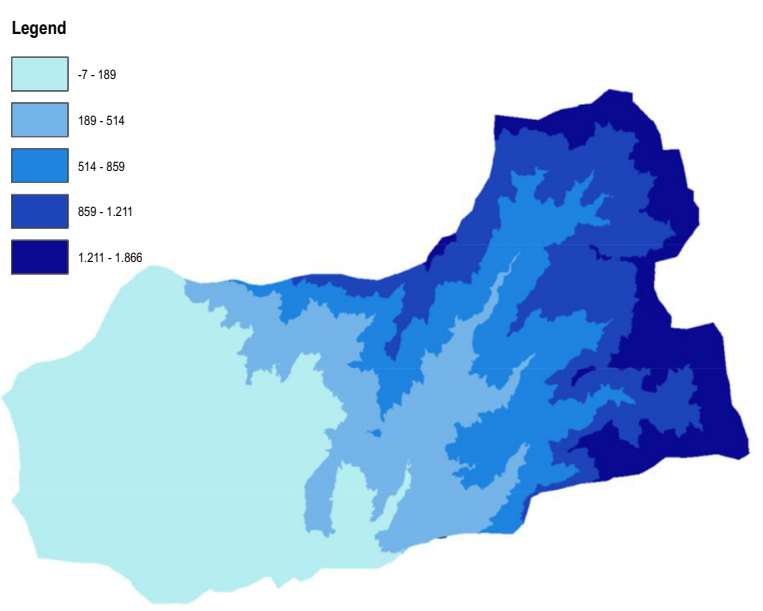

Fig. 1. DEM for Kuranji River watershed

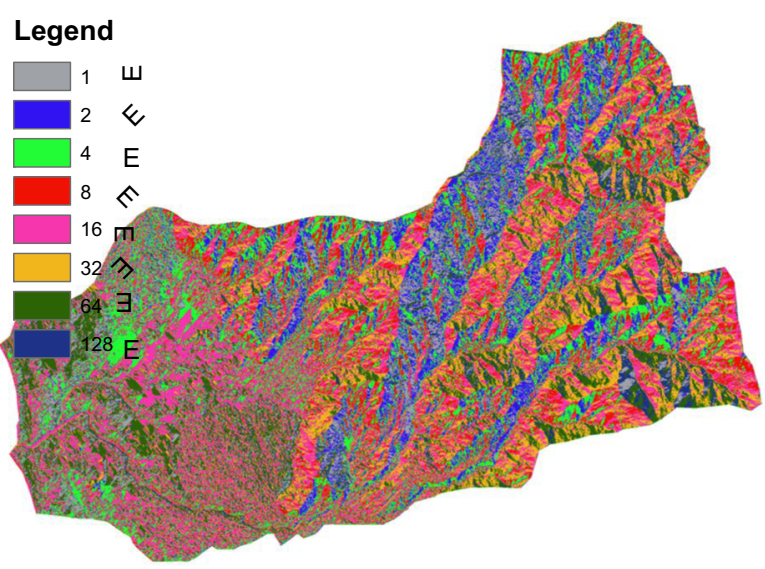

Fig. 2. Flow direction for Kuranji River watershed

The location of the Batang Limau Manih sediment control building project is in the downstream area, as shown in the following Fig. 3 Check dam location.

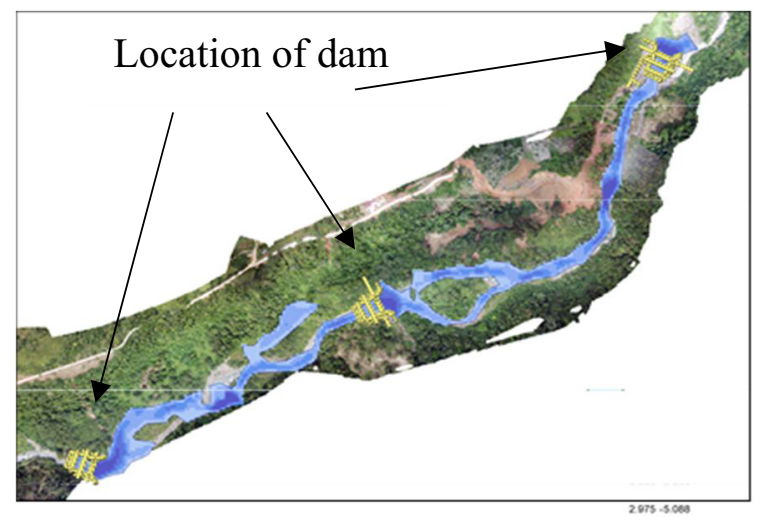

Fig. 3 Check dam location

The sediment control buildings built are in the form of three check dams, namely check dam ( I, check dam II, and check dam III ), Check dam ( I ) is at the highest elevation compared to the other two check dams.

\subsection{Flood discharge}

Hydrological analysis was carried out to find the value of flood discharge with a return period of 25 years, 50 years,
100 years, 500 years, and 1000 years. The data used in this hydrological analysis is the maximum rainfall data from three rain stations, namely Batu Busuak Station, Gunung Nago Station, and Ladang Padi Station. The results of the calculation of the design rainfall with the Pearson-III Log distribution and the design flood discharge are obtained as shown in Table 1.The watershed of Batang Limau Manih and Debit below.

Table 1.The watershed of Batang Limau Manih and Debit

\begin{tabular}{|c|c|c|c|c|}
\hline \multirow{3}{*}{\multicolumn{3}{|c|}{$\begin{array}{l}\text { Area (A) } \\
\text { Flow Coefficient }(\mathrm{C}) \\
\text { Time of concentration }(\mathrm{Tc})\end{array}$}} & 30.0 & \multirow[t]{2}{*}{$\mathrm{km}^{2}$} \\
\hline & & & 0.65 & \\
\hline & & & 83.387 & minute \\
\hline $\begin{array}{l}\text { Return } \\
\text { period }\end{array}$ & $\begin{array}{c}\text { Tc } \\
\text { (jam) }\end{array}$ & $\begin{array}{l}\text { R 24 } \\
\text { (mm) }\end{array}$ & I (mm/jam) & $\begin{array}{c}\mathbf{Q} \\
\left(\mathbf{m}^{3} / \mathbf{s}\right)\end{array}$ \\
\hline 25 & 1.4 & 195 & 54 & 294 \\
\hline 50 & 1.4 & 203 & 56 & 305 \\
\hline 100 & 1.4 & 209 & 58 & 314 \\
\hline 500 & 1.4 & 215 & 60 & 323 \\
\hline 1000 & 1.4 & 227 & 63 & 341 \\
\hline
\end{tabular}

\subsection{The surface area of water}

The water surface area was carried out using the HECRAS 5.0.3 software. The data needed to analyze the water surface area are flood discharge, detailed map of river situation, and cross-section of the river. Using the HECGeo RAS tool, detailed situation maps and river crosssections in ArcGIS can be exported to HEC-RAS.

In the analysis of the water surface area, the river cross-section data is assumed to be unchanged, except for the cross-sectional data at the check dam location station. The manning coefficient value entered is 0.03 , except for the check dam cross-section, the value entered is 0.012 . The water surface area at the project site is as shown in Table 2. Differences in the surface area of the water.

Table 2. Differences in the surface area of the water

\begin{tabular}{|c|c|c|c|c|}
\hline TR & $\begin{array}{c}\text { Discharge } \\
\left(\mathrm{m}^{3} / \mathrm{s}\right)\end{array}$ & $\begin{array}{c}\text { Without } \\
\text { Weir } \\
(\mathrm{ha})\end{array}$ & $\begin{array}{c}\text { With } \\
\text { weir } \\
\text { (ha) }\end{array}$ & $\begin{array}{c}\text { Positive/ } \\
\text { negative } \\
(\%)\end{array}$ \\
\hline 25 & 293.6 & 10.3 & 10.2 & -1.1 \\
\hline 50 & 304,6 & 10.4 & 10.2 & -1.7 \\
\hline 100 & 314.4 & 10.5 & 10.4 & -1.6 \\
\hline 500 & 323.2 & 10.6 & 10.7 & 1.1 \\
\hline 1000 & 341.0 & 10.8 & 10.9 & 1.1 \\
\hline
\end{tabular}

\subsection{Water surface area analysis}

Analysis of the results of the water surface area is carried out through reading the inundation map obtained through several simulations. Each simulation is limited by the magnitude of the design flood discharge as input to the Arc-GIS in addition to the cross-section of the river. Simulations were carried out in two scenarios before the building and after the check dam. The picture shows a series of changes in the water surface area of the three check dams built. Analysis of the results of the water surface area is carried out through reading the inundation map obtained through several simulations. Each simulation is limited by the magnitude of the design flood 
discharge as input to the Arc-GIS in addition to the crosssection of the river. Simulations were carried out in two scenarios before the building and after the check dam. The picture shows a series of changes in the water surface area of the three check dams built.

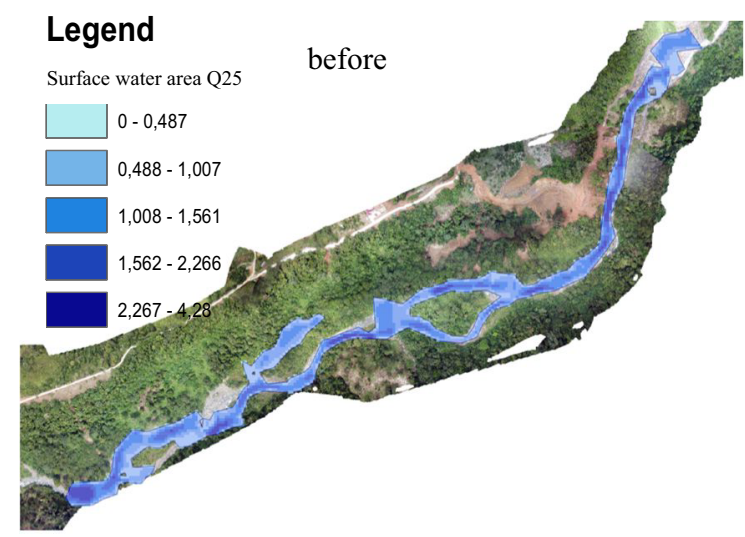

Fig. 4 Surface water area Q 25 (before)

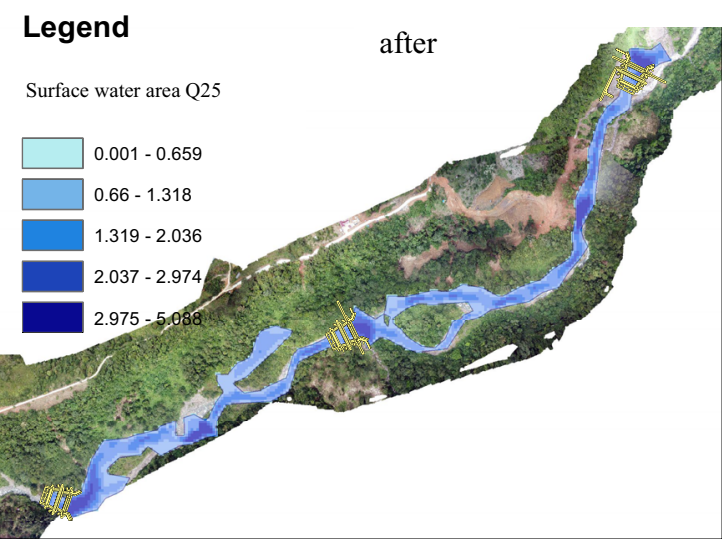

Fig. 5 Surface water area Q 25 (after)

If you look at the simulation results of the planned flood discharge with a return period of 25 years with 50 years, the change in the inundation area is not very visible. This is because the difference in discharge is not too large. However, if it is observed for changes in a discharge after 50 years, namely 100 years and 500 years, it has begun to be seen that the difference in inundation area is starting to be significant This shows the function and location of the check dam meet the requirements [8], holding sediment and escape the water [15], [16]. Please look at the following picture in fig 6,7,8,9,10 and 11 .

In the picture, it can be seen that the change in the inundation area in the image is not very visible because the image scale is too large. But something is interesting, namely the change in water level upstream of the weir. The change in depth increases with the greater the water discharge. The inundation should be bigger upstream of the weir, but it is not visible in the simulation because in the geometric design the channel cross-section is widened at each upstream of the weir. In addition, the dimensions of the embankment are increased enough to accommodate a 500-year (Q500), so that water can not overflow to the side of the river [17], [18], [19].

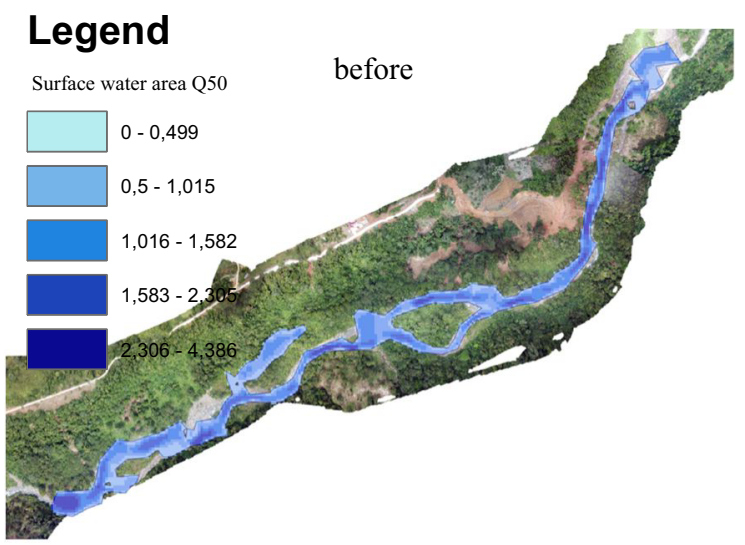

Fig. 6 Surface water area Q 50 (before)

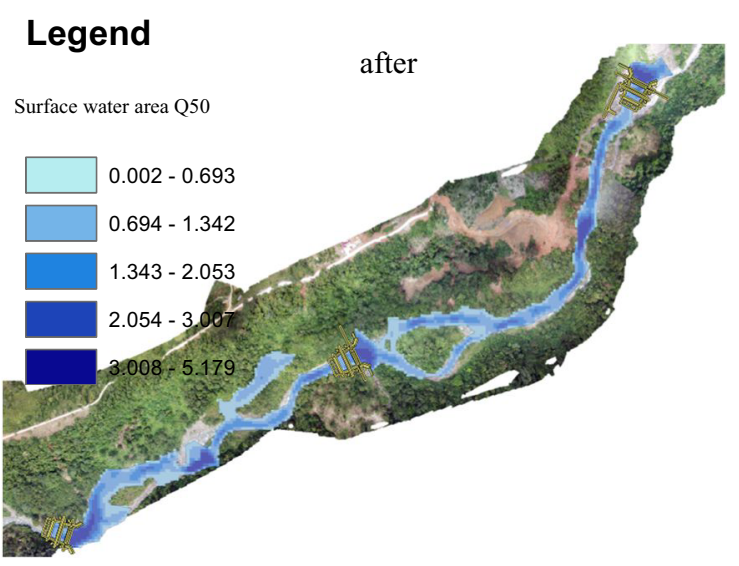

Fig. 7 Surface water area Q 50 (after)

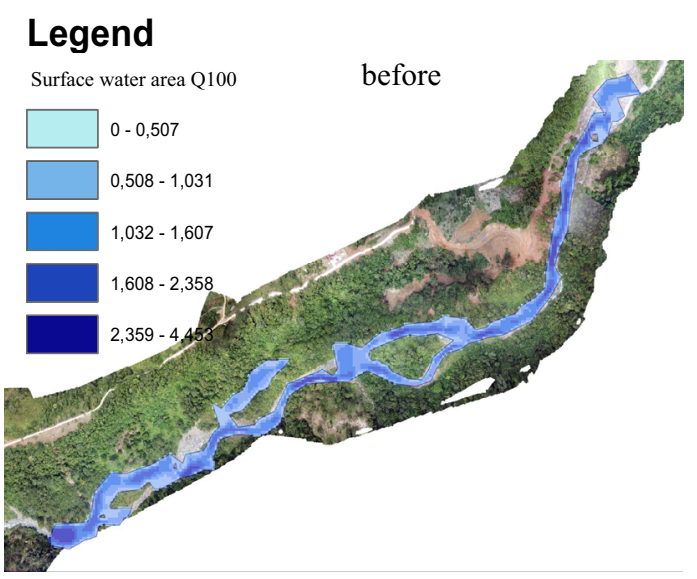

Fig. 8 Surface water area Q 100 (before)

Overall the weir can provide security against water overflows both upstream and downstream of the weir. However, due to the presence of a dam, the water level increases, where discharge in the 100-year and 500-year simulations, the dam's level is already high. So that the flow velocity after the weir is still high due to the release of potential energy and causes the downstream scour to enlarge [8], the long-term effect must be considered [20].

Physically there has been erosion downstream of the weir, especially the waterfall area. Then there is also erosion and sediment deposition along the channel after the main weir building. 


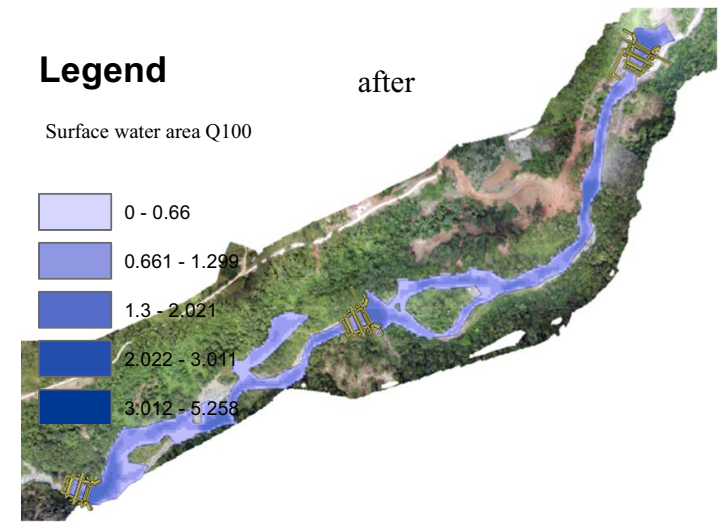

Fig. 9 Surface water area Q 100 (after)

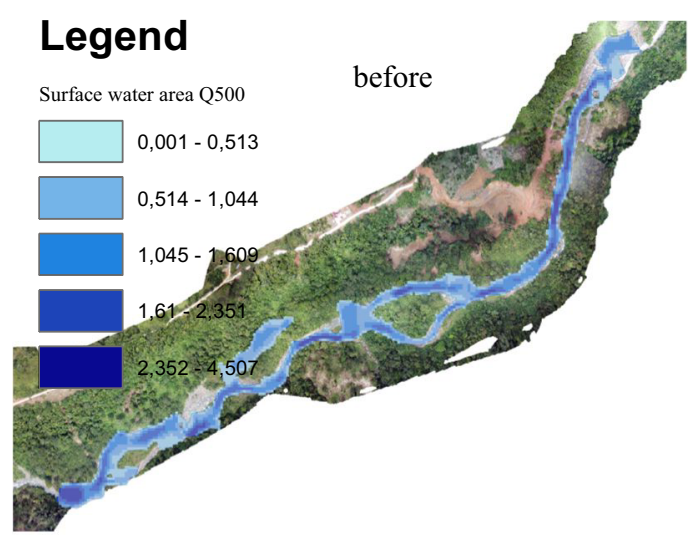

Fig. 10 Surface water area Q 500 (before)

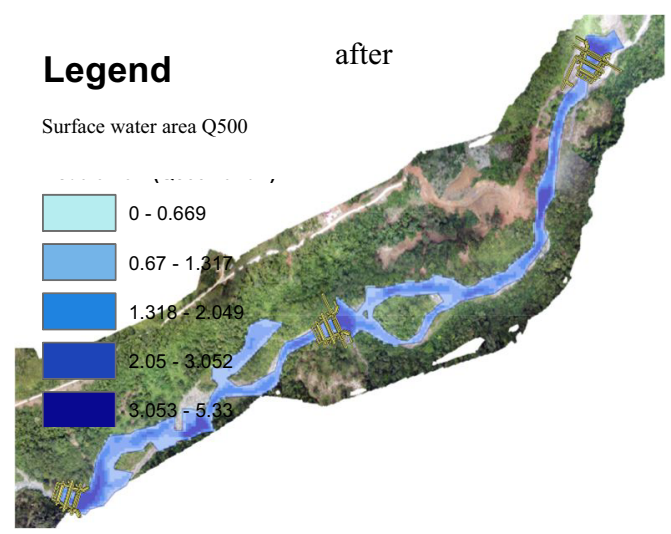

Fig. 11 Surface water area Q 500 (after)

\section{Conclusion}

In the impact study of the construction of the Batang Limau Manih sediment control building, it can be concluded that:

1. The location of the check dam on the Batang Limau Manih is quite good, where the water level rise upstream of the weir did not reach the next weir.

2. The water surface area due to the construction of sediment control structures does not significantly reduce or increase the water surface area that occurs. This is due to the widening of the channel cross-section upstream of the weir.

3. The construction of a check dam can affect the water level upstream and will increase the flow velocity and kinetic energy downstream of the weir.
This publication was funded by Andalas University through a publication grant from the Faculty of Engineering, Andalas University No. 122/UN16.09. D./PP/2021, and I would like to thank the Head of the Civil Engineering Department, Vice, Dean-1, Dean, and the Rector for their help.

\section{References}

1. D. Daoed, R. Bujang, Istijono, A. Hakam. Predictions of Vulnerability Flood and Flood Prone Areas in Watershed West Sumatra Province using Arc-GIS and Category Value. International Journal of Earth Sciences and Engineering, 09 SPL No 03(3rd International Conference on Earth Sciences and Engineering (ICEE 2016) 17th-18th June 2016), 274-279. (2016).

2. K. Subramanya, Engineering Hydrology (Vol. Third Edition). New Delhi: Tata McGraw-Hill Publishing Company Limited. (2008).

3. J, S. Kodoatie Robert, Flood Causes and Control Methods From an Environmental Perspective. Yogyakarta: Pustaka Pelajar. (2002).

4. Ministry of Public Works and Public Housing, (B. K. P). To Prevent Flash Floods From Recurring, Ministry of PUPR Completes Padang City Flood and Sediment Control. (2018).

5. D. Daoed, M. Syukur, \& M. Rahman, Habibur.The Effect of Land Use Changes on Flow and Drainage Systems Using Geographic Information Systems (GIS) Case Study: Andalas University Campus Area, Padang. Paper presented at the National Conference 3 (3rd ACE Engineering), Padang, Sumatra Barat. (2016).

6. A. Armanini, F. Dellagiacoma, \& L. Ferrari, From the check dam to the development of functional check dams Fluvial hydraulics of mountain regions (pp. 331-344): Springer. (1991).

7. Ministry of Public Works and Public Housing, P. K. P.. Batang Kuranji Flood and Sediment Control Efforts in Padang City. (2015).

8. A. Armanini, \& M. Larcher, Rational criterion for designing opening of slit-check dam. Journal of Hydraulic Engineering, 127(2), 94-104. (2001)

9. BNPB (National Disaster Management Agency). Regulation of the Head of the National Disaster Management Agency Number 8 About Standardization of Disaster Data. Jakarta. (2011).

10. D. Daoed, R. Bujang, Istijono,. M. Syukur, Evaluation of Drought Vulnerability on Watersheds in West Sumatera Province by Using Cropwat-8 and GIS. International Journal on Advanced Science, Engineering and Information Technology, 8(6), 2443-2449. (2018).

11. L. Utami, \& Sylvia. Study of Empirical Methods for Calculating the State River Flood Discharge in the Sungai Pandan Sub-District.Jurnal Poros Teknik., 103, (2016).

12. M. S. J. H. G. Kang, J.A. Song, Y.G. Chu, S.W. Her, S.W. Hwang, Park. Estimating Design Floods Based 
on the Critical Storm Duration for Small Watershed. Journal of HydroEnvironment Research, 7. (2013).

13. M. Aziz, \& S. Pujino, Desktop and Web-Based Geographic Information System. Yogyakarta: Gava Media (2006).

14. A. Padmavathy, K. G. Raj, N. Yogarajan, P. Thangavel, \& M. Chandrasekhar, Check dam site selection using GIS approach. Advances in Space Research, 13(11), 123-127. (1993).

15. A. Romero-Díaz, F. Alonso-Sarriá, \& M. MartínezLloris, Erosion rates obtained from check-dam sedimentation (SE Spain). A multi-method comparison. Catena, 71(1), 172-178. (2007).

16. A. M. Hassanli, A. E. Nameghi, \& S. Beecham, Evaluation of the effect of porous check dam location on fine sediment retention (a case study).
Environmental monitoring and assessment, 152(1), 319-326. (2009).

17. J. M. Andrew Chadwick, Hydraulics in Civil Engineering. London: Allen \& Unwin Ltd, (1986)

18. D. Daoed, Hydraulics and Applied for Open Channels, Padang, CV Ferila. (2010).

19. C. N. Ezugwu, Sediment Deposition in Nigeria Reservoirs: Impacts and Control Measures. Innovative Systems Design and Engineering, 4 No 15(Sediment), 8. (2013).

20. K. N. Ratnam, Y. Srivastava, V. Rao, E. Amminedu, \& K. Murthy, Check dam positioning by prioritization of micro-watersheds using SYI model and morphometric analysis - remote sensing and GIS perspective. Journal of the Indian society of remote sensing, 33(1), 25-38. (2005) 